\title{
Extra-pair paternity and antiparasitic defence
}

\author{
Anders Pape Møller ${ }^{1,2^{*}}$, Jørgen Skavdal Søraker ${ }^{3}$ id and Juan José Soler ${ }^{4}$
}

\begin{abstract}
Background: Extra-pair paternity (EPP) in birds provides benefits in terms of more offspring, and characteristics for maintenance of this behaviour have been the subject of investigation. Microorganisms are known to be transmitted during mating, especially when mating with multiple partners, and factors reducing this cost of multiple mating are expected. Further, plumage brightness and colour intensity have been shown to be important traits to benefits from multiple mating as predicted by sexual selection. The aim of this study was to investigate the relationship between the rate of extra-pair paternity and the relative size of the uropygial gland at the interspecific level, as the uropygial gland is an exocrine gland hypothesized to produce antiparasitic substances and further identified to affect plumage brightness. Because of the expected benefits of large uropygial gland in scenarios of sexual selection, we predicted a positive correlation with EPP.
\end{abstract}

Methods: We collected information from the literature of uropygial gland size and frequency of extra-pair paternity of 60 avian species of different families and explored the predicted positive correlation between them. We did so with means of comparative analyses that considered phylogenetic relationship as random factor and included body mass as covariate. We used Markov chain Monte Carlo generalized linear mixed models that were weighted by number of nests used to estimate extra-pair paternity.

Results: We detected a positive relationship between level of extra-pair paternity and uropygial gland size at an interspecific level. This finding is consistent with the prediction.

Conclusions: We discuss the importance of this result in scenarios of sexual selection and argue that the detected relationship may have arisen by utilizing antiparasitic secretions through secondary sexual characters indicating parasite resistance.

Keywords: Antiparasitic defence, Costs of extra-pair paternity, Microorganisms, Uropygial gland, Uropygial secretions

\section{Background}

Extra-pair paternity (EPP) has received great attention during recent decades, after Trivers (1972) argued that males should seek additional copulations, while females should choose males that could increase the genetic quality or the genetic constitution of offspring. Several hypotheses have been put forward to achieve a better

\footnotetext{
*Correspondence: anders.moller@u-psud.fr

${ }^{1}$ Ministry of Education Key Laboratory for Biodiversity Science

and Ecological Engineering, College of Life Sciences, Beijing Normal University, Beijing 100875, China

Full list of author information is available at the end of the article
}

understanding of the potential benefits of this behaviour. Empirical studies have found support for different benefits, although most attention has been given to the "good genes" hypothesis, predicting that females use male phenotypic cues to assess male genetic quality from which the offspring might benefit (Westneat et al. 1990; Birkhead and Møller 1992; Hasselquist et al. 1996; Griffith et al. 2002). Alternatively, "compatible genes" where the genes of an extra-pair male fit better with the genes of the female than those of the social partner may increase offspring fitness (Kempenaers et al. 1999; Tregenza and Wedell 2000; Griffith and Immer 2009). 
Females' benefits from EPP may also include fertility insurance (Birkhead and Møller 1992; Sheldon 1994; Schmoll and Kleven 2016) and access to resources (Wolf 1975; Gray 1997). However, these benefits have received less empirical support (Griffith et al. 2002). Social mates pay the main costs are loss of parental care (Birkhead et al. 1993; Suter et al. 2009), while costs of partner assessment (Petrie and Kempenaers 1998) and transmission of sexually transmitted diseases (Sheldon 1993) have also been suggested for males and females involved in EPP.

The Hamilton and Zuk hypothesis predict that females should choose mates with signals reliably reflecting resistance against parasites in the context of sexual selection (Hamilton and Zuk 1982; Møller 1990). Males expressing resistance to parasites may provide more parental care, as they suffer lower rates of parasites (Milinski and Bakker 1990), but also transmit resistance genes to offspring, which also benefit females (Hamilton and Zuk 1982). Regardless of the explanation, males revealing their resistance to potential female partners will more likely obtain extra-pair copulations. This was demonstrated for instance in the House Finch (Carpodacus mexicanus) in which carotenoid-based feather coloration was negatively correlated with the amount of featherdegrading bacteria (Shawkey et al. 2009), while poor male condition was related to the presence of other parasites (Thompson et al. 1997). Thus, males signalling his phenotypic quality including resistance to parasitism will more easily access to females including extra-pair females.

However, extra-pair copulations would also imply the transmission of microorganisms between males and females, which may have beneficial (Lombardo et al. 1999) or pathogenic effects. Costs of EPP associated to parasitism and/or antiparasitic defences are in case scarcely studied. As examples of parasites' transmission during copulation, Ring-necked Pheasants (Phasianus colchicus) are known to transmit ectoparasites from male to female during copulation (Hillgarth 1996). Thus, as mating with several partners will expose individuals to potential parasite transmission, this could affect both individuals and the outcome of the reproductive event. Any males with superior resistance should be better to avoid potential costs or simply be better adapted to reduce the consequences for the costs of extra-pair paternity. Since birds usually signal their antiparasitic capabilities throughout plumage brightness (Hamilton and Zuk 1982), related characters should also play a crucial role describing which males could gain multiple mating. Hence, understanding potential relationships between parasites and defence mechanisms should help understand the underlying mechanisms behind EPP (Westneat and Stewart 2003).
By definition, secondary sexual traits are important for gaining multiple mating, and these traits are often reflected in colour and brightness (Baker and Parker 1979), which, as mentioned before, usually reveals resistance of individuals to parasitic infection (Hamilton and Zuk 1982). Several secondary sexual traits, including feather coloration, are condition-dependent, hence indicating high-quality individuals (Andersson 1994). It is known for instance that more colourful individuals in the Greater Flamingo (Phoenicopterus roseus) had higher breeding success (Amat et al. 2011), and that plumage brightness was related to chick development in Blue Tits (Cyanistes caeruleus) (Senar et al. 2002), both results suggesting a direct link between feather coloration and important fitness components. Thus, any characteristics that prevented feather deterioration or enhance parasite resistance will be sexually selected and, consequently, should predict the strength of sexual selection. The uropygial gland is a good candidate trait, mainly because its main function is to protect feathers from degradation agents including microorganisms (Moreno-Rueda 2017; Azcárate-García et al. 2020) but also because its size or volume of secretion predicts selection pressures due to ectoparasites (Magallanes et al. 2016).

The objective of this study was to test the prediction relating EPP and the size of the uropygial gland among 60 bird species. The relationship between the size of the uropygial gland and bacterial diversity has been investigated several times (Møller et al. 2009; Jacob et al. 2014). Secretions from the uropygial gland have been demonstrated to act as antiparasitic defence in some species, although generally assumed for many species, especially against feather-degrading bacteria (Jacob and Ziswiler 1982; Møller et al. 2009; Ruiz-Rodríguez et al. 2009), which can affect interspecific interactions such as predation (Møller et al. 2010), but also sexually selected feathers (Ruiz-Rodríguez et al. 2015). Simultaneously, secretions from the uropygial gland have been shown to increase colour intensity (Amat et al. 2011) and affect plumage brightness (Moreno-Rueda 2010). However, the relationship between EPP and the uropygial gland remains poorly understood. Here we provide, to our knowledge, the first test of the hypothesis that the level of EPP is positively related to the size of the uropygial gland, which will suggest a direct link between uropygial gland and the strength of sexual selection.

\section{Methods}

\section{Uropygial gland}

Uropygial gland data from Jacob and Ziswiler (1982)

We extracted information on the size of the uropygial gland using Jacob and Ziswiler (1982) as a source. We assumed that a larger uropygial gland could produce 
more secretions than a smaller gland, which was demonstrated at an intraspecific level in Barn Swallows (Hirundo rustica) (Møller et al. 2009) and is discussed at the interspecific level by Soler et al. (2012).

\section{Extra-pair paternity data}

Estimates of species-specific extra-pair paternity rate were extracted from Griffith et al. (2002). Extra-pair paternity was defined as the proportion of offspring that was extra-pair offspring. In a second data set we used the proportion of broods that held extra-pair offspring. Data since 2002 were extracted from the Web of Science. In total, estimates of both EPP and uropygial gland size were available for 60 species (Additional file 1: Table S1).

\section{Body mass}

Body mass was extracted from Dunning (2008).

\section{Comparative analysis}

Species characteristics are not statistically independent because they share their evolutionary history. We adjusted for this dependence using comparative analyses. We controlled for phylogenetic uncertainty, using phylogenetic relationships among species. This was done by using 100 phylogenetic ultrametric trees for all the species included in the analysis from https://birdt ree.org/ (accessed April 2020). All models were fitted to the different trees by using Bayesian phylogenetic models from the MCMCglmm package (Hadfield 2010). The MCMC algorithm was set to 2,000,000 iterations, with a burn-in period of 100,000 and a thinning interval of 1000. Geweke's convergence diagnostic was used for Markov chains, giving a $z$-score of the first $10 \%$ and last $50 \%$ of the means in the chain (Geweke 1992). The models use the frequency of EPP (proportion of broods with extra-pair paternity) as response variable, and $\log _{10}$-transformed uropygial gland size from Jacob and Ziswiler (1982), $\log _{10}$-transformed body mass from Dunning (2008) and sample sizes for EPP as explanatory continuous variables. Model 1 assumes Poisson distribution, while Model 2 assumes Gaussian distribution, and these models are further weighted for sample size to account for uneven sampling effort (Garamszegi and Møller 2010). Tests of the random effect of phylogeny for the 100 phylogenetic trees was performed and assessed as heritability $\left(h^{2}\right)$, a measure of phylogenetic signal ranging between zero and one (Hadfield 2010). For all the independent factors $\left(\log _{10}\right.$-transformed uropygial gland size, $\log _{10}$-transformed body mass and sample sizes for $\mathrm{EPP})$, the averaging estimates, lower and upper values of the confidence interval ( $95 \% \mathrm{CI}$ ), calculated as upper and lower $95 \%$ credibility interval values of the estimates of the 100 models, the $95 \%$ CI for the 100 models for
pMCMC values, $z$-score of the Geweke's convergence diagnostic, effective sample sizes and autocorrelations are reported.

\section{Results}

Uropygial gland size and EPP

When corrected for phylogeny in comparative analyses, there was a significant positive relationship between level of EPP and size of the uropygial gland for both models (Fig. 1) and body mass, but not with sample sizes for EPP (Table 1). The size of the uropygial gland is from previous studies known to correlate positively with body size (Møller et al. 2010) and the amount of wax produced (Elder 1954; Møller et al. 2009; Pap et al. 2010). Hence, we assume that the size of the uropygial gland represents the relative amount of wax and, thus, larger amounts of the antiparasitic defence properties that can affect the integrity of feathers, hence give plumage in better condition (Azcárate-García et al. 2020) as well as their coloration and brightness (Amat et al. 2011; Moreno-Rueda 2017).

\section{Discussion}

The main finding in this study is that the size of the uropygial gland is positively related to the level of EPP at the interspecific level. This is in line with the predictions regarding the role of secretions of the uropygial gland in both antimicrobial defence and plumage brightness (Moreno-Rueda 2017). The specific function of the uropygial gland on these two processes, however, remains unknown.

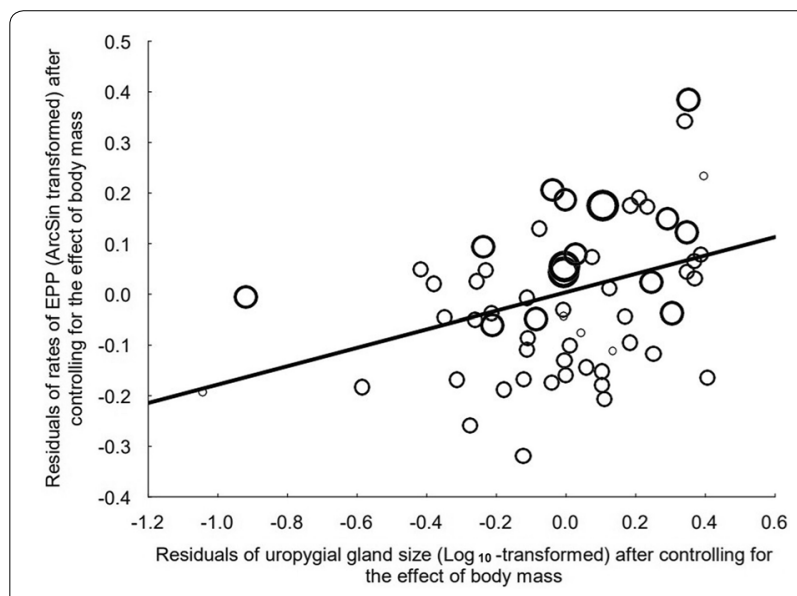

Fig. 1 Association between residuals of rate of extra pair paternity and volume of the uropygial gland of the 60 avian species considered in the study after controlling for the effect of body mass. Line is the regression line and size of circles are proportional to $\log _{10}$-transformed sample size used to estimate extra pair paternity in each species 


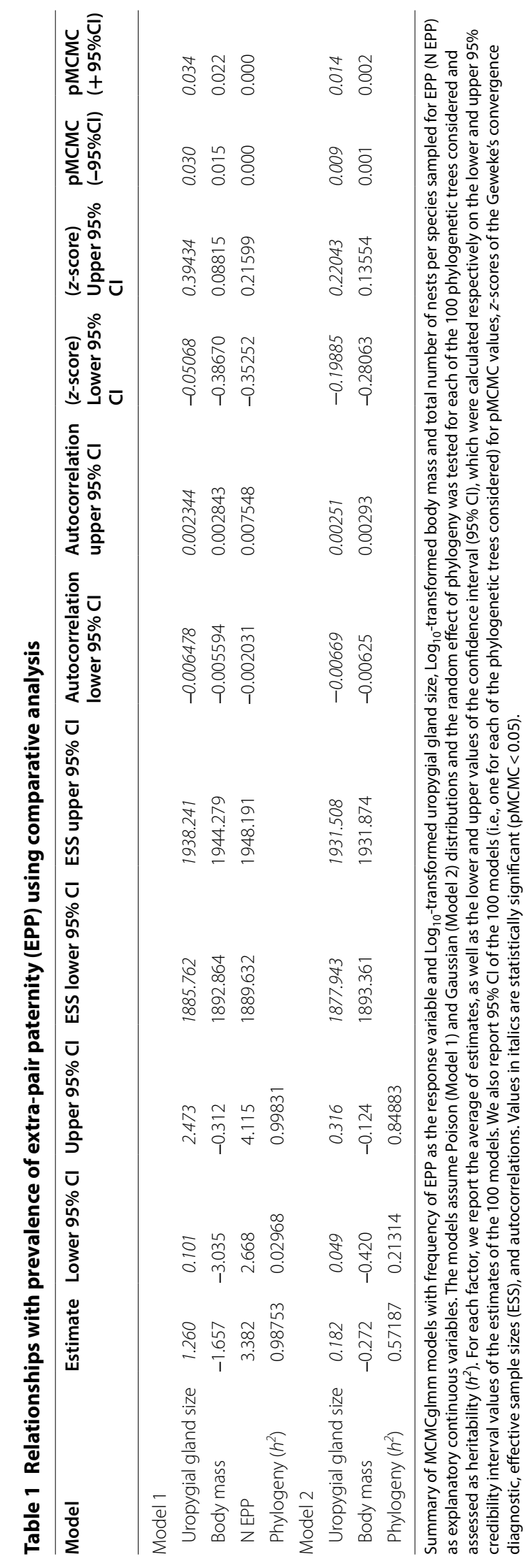


Previous studies have documented transmission of microorganisms from males to females through mating events (Hillgarth 1996; Westneat and Rambo 2000) and other social events (Brown et al. 2001). This mechanism is one of few, but still poorly understood costs of EPP. However, the related costs can be of crucial importance in order to maintain this behaviour (Westneat and Stewart 2003), and mechanisms to reduce the costs are expected. The size of the uropygial gland is positively related to the amount of secretions produced for a variety of species (Elder 1954; Møller et al. 2010; Pap et al. 2010) as the gland is made up of tubules where secretion of the substances occur (Jacob and Ziswiler 1982), and secretions are hypothesized to have antiparasitic substances (Moreno-Rueda 2017). Hence, selection for defence through uropygial gland secretions could be an important factor for fitness components such as reproductive success (Whittaker et al. 2013) and survival (Merino et al. 2000; Møller et al. 2010; Magallanes et al. 2017).

Both Møller et al. (2010) and Soler et al. (2012) documented a relationship between bacterial abundance and load with size of the uropygial gland, with the substances secreted by the gland hypothesised to act as antimicrobial defence. Here, we demonstrated that, when corrected for phylogeny, the level of EPP was positively related to uropygial gland size. Due to the potential transmission of bacteria through mating (Hillgarth 1996; Westneat and Rambo 2000), the relatively increased size of the uropygial gland, and hence amount of wax, could be an important defence mechanism to reduce this cost. Hence, we suggest that the increased size of the uropygial gland, and further the amount of wax, may have arisen as coevolutionary responses to reduce the associated costs of EPP.

Species with higher intraspecific levels of EPP often show more intense selection on secondary sexual traits, caused by greater variance in reproductive success (Yezerinac et al. 1995; Møller 1997; Whittingham and Dunn 2005). Furthermore, there is a negative relationship between secondary sexual ornaments and the loss of within-pair paternity (Møller and Ninni 1998). Several hypotheses have linked the intensity of secondary sexual traits to parasite resistance, such as the Hamilton-Zuk (1982) hypothesis. The size of the uropygial gland has been shown to correlate positively with secondary sexual traits (Moreno-Rueda 2010), plumage brightness (Møller and Mateos-González 2019) and colour intensity (Amat et al. 2011). Moreover, ornamental feathers are more easily degraded by bacteria (Ruiz-Rodríguez et al. 2015; Azcárate-García et al. 2020), and individuals with larger uropygial glands were those better protecting their ornamental feathers from degradation, which could result in more attractive plumage (Ruiz-Rodríguez et al. 2015). Hence, secretions from the uropygial gland can be an important factor promoting the acquisition of gain extrapair copulations since several of these are likely to be condition-dependent (Andersson 1994).

In light of this finding, uropygial gland is likely influenced by sexual selection, but more research is needed in order to acquire a better understanding of the role of the uropygial gland in EPP. Studies using a representative measure of feather bacteria are needed to investigate the effect of uropygial gland secretions in relation to EPP. Furthermore, a similar interspecific investigation is needed regarding plumage brightness and coloration, although a positive relationship is found in species-specific studies (Galvan and Sanz 2006; Moreno-Rueda 2010; Amat et al. 2011). However, these two processes are not mutually exclusive, and they may act simultaneously as described here.

\section{Conclusions}

Here we demonstrate, to our knowledge, the first finding of a positive relationship between the size of the uropygial gland and the level of EPP. This, together with previous findings of the role of uropygial gland, suggest that the size of uropygial gland size could be selected for through exaggeration of secondary sexual traits and/or signalling antimicrobial defence mechanism. This provides important insight to the role of secretions by the uropygial gland on EPP. Future investigations should focus on the effect of uropygial gland secretions and explore the relationship between EPP and size of uropygial gland at an intraspecific level.

\section{Supplementary information}

Supplementary information accompanies this paper at https://doi. org/10.1186/s40657-020-00226-5.

Additional file 1: Table S1. Sample size of avian nests used to estimate prevalence of extra-pair paternity of the 60 bird species used in the study.

\section{Acknowledgements}

We would like to thank Camilla Marnor, Simen C. Karlsen, Mikael A. Sætre and Per H. Rishøi for discussion of the literature in early parts of the study. Jordi Moya help us to implement R'scripts to perform the analyses of the 100 phylogenetic trees considered at the same time.

\section{Authors' contributions}

APM conceived the idea. APM extracted the data. JJS made the comparative analyses. APM and JSS wrote the paper. All authors read and approved the final manuscript.

\section{Funding}

JJS received financial support by the Spanish Ministerio de Ciencia, Innovación y Universidades and European (FEDER) funds (CGL2017-83103-P).

Availability of data and materials

The data on which this paper was made are fully available at the appendix of the manuscript. 
Ethics approval and consent to participate

Not applicable.

\section{Consent for publication}

Not applicable.

\section{Competing interests}

The author declares no competing interests.

\section{Author details}

${ }^{1}$ Ministry of Education Key Laboratory for Biodiversity Science and Ecological Engineering, College of Life Sciences, Beijing Normal University, Beijing 100875, China. ${ }^{2}$ Ecologie Systématique et Evolution, Université Paris-Saclay, CNRS, AgroParisTech, 91405 Orsay, France. ${ }^{3}$ Centre for Biodiversity Dynamics, Department of Biology, Norwegian University of Science and Technology, Høgskoleringen 5, No-7491, Trondheim, Norway. ${ }^{4}$ Depto. Ecología Funcional y Evolutiva, Estación Experimental de Zonas Áridas, Ctra. Sacramento S/N, La Cañada de San Urbano, 04120 Almería, Spain.

Received: 15 July 2020 Accepted: 8 October 2020

Published online: 14 October 2020

\section{References}

Amat JA, Rendón MA, Garrido-Fernández J, Garrido A, Rendón-Martos M, Pérez-Gálvez A. Greater flamingos Phoenicopterus roseus use uropygia secretions as make-up. Behav Ecol Sociobiol. 2011;65:665-73.

Andersson MB. Sexual selection. Princeton: Princeton University Press; 1994

Azcárate-García M, González-Braojos S, Díaz-Lora S, Ruiz-Rodríguez M, MartínVivaldi M, Martínez-Bueno M, et al. Interspecific variation in deterioration and degradability of avian feathers: the evolutionary role of microorganisms. J Avian Biol. 2020:51:e02320.

Baker RR, Parker G. The evolution of bird coloration. Philos T Roy Soc B. 1979:287:63-130.

Birkhead TR, Møller AP. Sperm competition in birds. Evolutionary causes and consequences. San Diego: Academic Press; 1992.

Birkhead T, Møller A, Sutherland W. Why do females make it so difficult for males to fertilize their eggs? J Theor Biol. 1993;161:51-60.

Brown CR, Komar N, Quick SB, Sethi RA, Panella NA, Brown MB, et al. Arbovirus infection increases with group size. Proc R Soc B Biol Sci. 2001:268:1833-40.

Dunning JB. CRC handbook of avian body masses. 2nd ed. Boca Raton, FL: CRC Press; 2008

Elder WH. The oil gland of birds. Wilson Bull. 1954;66:6-31.

Galvan I, Sanz JJ. Feather mite abundance increases with uropygial gland size and plumage yellowness in Great Tits Parus major. Ibis. 2006;148:687-97.

Garamszegi LZ, Møller AP. Effects of sample size and intraspecific variation in phylogenetic comparative studies: a meta-analytic review. Biol Rev. 2010;85:797-805

Geweke J. Evaluating the accuracy of sampling-based approaches to the calculations of posterior moments. Bayesian Stat. 1992;4:641-9.

Gray EM. Do female red-winged blackbirds benefit genetically from seeking extra-pair copulations? Anim Behav. 1997;53:605-23.

Griffith SC, Immler S. Female infidelity and genetic compatibility in birds: the role of the genetically loaded raffle in understanding the function of extrapair paternity. J Avian Biol. 2009;40:97-101.

Griffith SC, Owens IP, Thuman KA. Extra pair paternity in birds: a review of interspecific variation and adaptive function. Mol Ecol. 2002;11:2195-212.

Hadfield JD. MCMC methods for multi-response generalized linear mixed models: the MCMCglmm R package. J Stat Softw. 2010;33:1-22.

Hamilton WD, Zuk M. Heritable true fitness and bright birds: a role for parasites? Science. 1982;218:384-7.

Hasselquist D, Bensch S, von Schantz T. Correlation between male song repertoire, extra-pair paternity and offspring survival in the great reed warbler. Nature. 1996:381:229-32.

Hillgarth N. Ectoparasite transfer during mating in ring-necked pheasants Phasianus colchicus. J Avian Biol. 1996:27:260-2.

Jacob J, Ziswiler W. The uropygial gland. In: Farner DS, King JR, Parkes KC, editors. Avian biology, vol. VII. New York: Academic Press; 1982. p. 359-62.
Jacob S, Immer A, Leclaire S, Parthuisot N, Ducamp C, Espinasse G, et al. Uropygial gland size and composition varies according to experimentally modified microbiome in Great tits. BMC Evol Bio. 2014;14:134.

Kempenaers B, Congdon B, Boag P, Robertson RJ. Extrapair paternity and egg hatchability in tree swallows: evidence for the genetic compatibility hypothesis? Behav Ecol. 1999;10:304-11

Lombardo MP, Thorpe PA, Power HW. The beneficial sexually transmitted microbe (STM) hypothesis of avian copulation. Behav Ecol. 1999:10:333-7.

Magallanes S, Møller AP, García-Longoria L, de Lope F, Marzal A. Volume and antimicrobial activity of secretions of the uropygial gland are correlated with malaria infection in house sparrows. Parasites Vectors. 2016:9:1-8

Magallanes S, García-Longoria L, López-Calderón C, Reviriego M, de Lope F, Møller A, et al. Uropygial gland volume and malaria infection are related to survival in migratory house martins. J Avian Biol. 2017:48:1355-9.

Merino S, Møller AP, de Lope F. Seasonal changes in cell-mediated immunocompetence and mass gain in nestling barn swallows: a parasite-mediated effect? Oikos. 2000;90:327-32.

Milinski M, Bakker TC. Female sticklebacks use male coloration in mate choice and hence avoid parasitized males. Nature. 1990;344:330-3.

Møller AP. Parasites and sexual selection: current status of the Hamilton and Zuk hypothesis. J Evol Biol. 1990;3:319-28.

Møller AP. Immune defence, extra-pair paternity, and sexual selection in birds. Proc R Soc B Biol Sci. 1997;264:561-6.

Møller AP, Mateos-González F. Plumage brightness and uropygial gland secretions in barn swallows. Curr Zool. 2019;65:177-82.

Møller AP, Ninni P. Sperm competition and sexual selection: a meta-analysis of paternity studies of birds. Behav Ecol Sociobiol. 1998:43:345-58.

Møller AP, Czirjak GÁ, Heeb P. Feather micro-organisms and uropygial antimicrobial defences in a colonial passerine bird. Funct Ecol. 2009;23:1097-102.

Møller AP, Erritzøe J, Rózsa L. Ectoparasites, uropygial glands and hatching success in birds. Oecologia. 2010;163:303-11.

Moreno-Rueda G. Uropygial gland size correlates with feather holes, body condition and wingbar size in the house sparrow Passer domesticus. J Avian Biol. 2010;41:229-36.

Moreno-Rueda G. Preen oil and bird fitness: a critical review of the evidence. Biol Rev. 2017;92:2131-43.

Pap PL, Vágási Cl, Osváth G, Mureşan C, Barta Z. Seasonality in the uropygia gland size and feather mite abundance in house sparrows Passer domesticus: natural covariation and an experiment. J Avian Biol. 2010:41:653-61.

Petrie M, Kempenaers B. Extra-pair paternity in birds: explaining variation between species and populations. Trends Ecol Evol. 1998;13:52-8.

Ruiz-Rodríguez M, Valdivia E, Soler JJ, Martín-Vivaldi M, Martin-Platero A, Martínez-Bueno M. Symbiotic bacteria living in the hoopoe's uropygial gland prevent feather degradation. J Exp Biol. 2009;212:3621-6.

Ruiz-Rodríguez M, Tomas G, Martín-Gálvez D, Ruiz-Castellano C, Soler JJ. Bacteria and the evolution of honest signals. The case of ornamental throat feathers in spotless starlings. Funct Ecol. 2015;29:701-9.

Schmoll T, Kleven O. Functional infertility in a wild passerine bird. Ibis. 2016;158:670-3.

Senar JC, Figuerola J, Pascual J. Brighter yellow blue tits make better parents. Proc R Soc B Biol Sci. 2002;269:257-61.

Shawkey MD, Pillai SR, Hill GE. Do feather-degrading bacteria affect sexually selected plumage color? Naturwissenschaften. 2009;96:123-8.

Sheldon B. Sexually transmitted disease in birds: occurrence and evolutionary significance. Philos T Roy Soc B. 1993;339:491-7.

Sheldon B. Sperm competition in the chaffinch: the role of the female. Anim Behav. 1994:47:163-73.

Soler J, Peralta-Sánchez J, Martín-Platero A, Martín-Vivaldi M, Martínez-Bueno M, Møller A. The evolution of size of the uropygial gland: mutualistic feather mites and uropygial secretion reduce bacterial loads of eggshells and hatching failures of European birds. J Evol Biol. 2012;25:1779-91.

Suter SM, Bielańska J, Röthlin-Spillmann S, Strambini L, Meyer DR. The cost of infidelity to female reed buntings. Behav Ecol. 2009;20:601-8.

Thompson CW, Hillgarth N, Leu M, McClure HE. High parasite load in house finches (Carpodacus mexicanus) is correlated with reduced expression of a sexually selected trait. Am Nat. 1997;149:270-94.

Tregenza T, Wedell N. Genetic compatibility, mate choice and patterns of parentage: invited review. Mol Ecol. 2000;9:1013-27. 
Trivers RL. Parental investment and sexual selection. In: Campbell B, editor. Sexual selection and the descent of man, 1871-1971. Chicago: Aldine Press; 1972. p. 136-79.

Westneat DF, Rambo TB. Copulation exposes female Red-winged Blackbirds to bacteria in male semen. J Avian Biol. 2000;31:1-7.

Westneat DF, Stewart IRK. Extra-pair paternity in birds: causes, correlates, and conflict. Annu Rev Ecol Syst. 2003;34:365-96.

Westneat DF, Sherman PW, Morton ML. The ecology and evolution of extrapair copulations in birds. Curr Ornithol. 1990;7:331-69.

Whittaker DJ, Gerlach NM, Soini HA, Novotny MV, Ketterson ED. Bird odour predicts reproductive success. Anim Behav. 2013;86:697-703.
Whittingham LA, Dunn PO. Effects of extra-pair and within-pair reproductive success on the opportunity for selection in birds. Behav Ecol. 2005;16:138-44.

Wolf LL. "Prostitution" behavior in a tropical hummingbird. Condor. $1975 ; 77: 140-4$

Yezerinac SM, Weatherhead PJ, Boag PT. Extra-pair paternity and the opportunity for sexual selection in a socially monogamous bird (Dendroica petechia). Behav Ecol Sociobiol. 1995;37:179-88.
Ready to submit your research? Choose BMC and benefit from:

- fast, convenient online submission

- thorough peer review by experienced researchers in your field

- rapid publication on acceptance

- support for research data, including large and complex data types

- gold Open Access which fosters wider collaboration and increased citations

- maximum visibility for your research: over $100 \mathrm{M}$ website views per year

At BMC, research is always in progress.

Learn more biomedcentral.com/submissions 